\title{
GUIDING QUESTIONS TECHNIQUE TO IMPROVE STUDENTS' WRITING SKILLS: RECOUNT TEXT
}

\author{
Siti Nuraeni Muhtar ${ }^{1}$, Lina Rustina ${ }^{2}$, R. Nadia R.P. Dalimunthe ${ }^{3}$ \\ Dosen UIN Sunan Gunung Djati Bandung ${ }^{1,3}$, Mahasiswa UIN Sunan Gunung Djati \\ Bandung \\ Jalan A.H. Nasution No. 104 Cibiru, Bandung \\ Sur-el : siti.nuraeni@uinsgd.ac.id ${ }^{1}$, linarustina17@gmail.com², \\ Rn.dalimunthe@uinsgd.ac.id ${ }^{3}$
}

\begin{abstract}
This research aimed to find out whether there was an improvement of the students' skills in writing recount text after using guiding questions as a technique of writing. The method applied in this research was a quantitative method which uses one group pre-test and post-test design. Random group sampling was utilized as the technique in taking a sample. After that, the researcher took one class consist of 31 of second grade students as research participants. This research was held in 6 meetings involved pre-test, four meetings for treatment, and post-test. The instrument of data collecting was a written test. In analyzing the data, the researcher used SPSS v. 16 and t-test.
\end{abstract}

Keywords: Guiding questions technique, Writing, Recount text

\begin{abstract}
Abstrak: Penelitian ini bertujuan untuk mengetahui apakah ada peningkatan keterampilan siswa dalam menulis teks 'recount' setelah menggunakan pertanyaan panduan sebagai teknik penulisan. Metode yang digunakan dalam penelitian ini adalah metode kuantitatif yang menggunakan desain satu kelompok 'pre-test' dan satu kelompok 'post-test'. Pengambilan sampel kelompok acak digunakan sebagai teknik dalam mengambil sampel. Setelah itu, peneliti mengambil satu kelas yang terdiri dari 31 siswa kelas dua sebagai peserta penelitian. Penelitian ini dilaksanakan dalam 6 pertemuan yang melibatkan 'pre-test', empat pertemuan untuk pengerjaan, dan 'post-test'. Instrumen pengumpulan data adalah tes tertulis. Dalam menganalisis data, peneliti menggunakan SPSS v.16 dan uji-t.
\end{abstract}

Kata Kunci: Teknik pertanyaan panduan, Menulis, Teks recount

\section{INTRODUCTION}

Writing is a way for people to express their ideas or assumptions in the sentences or paragraphs. Writing is one of the standard competencies that should be mastered by students. As cited in Ningrum (2015) one of four standard competencies that have to be learned by students is writing. In writing, students are hoped to be able to express many written meanings that have purposes in communicative, text structure based on Competence 2013. To create good writing is quite hard for people especially for students. Most of the students were also not able to construct sentences in past tense and arrange the sentences coherently (Wiliyanti, 2006). Pertiwi (2013) said in other words, although they have written several lines, they mostly find difficulties on how to continue their writing. In line with Wiliyanti and Pertiwi, Huy (2015) stated that writing is a complex metacognitive activity that draws on an individual's knowledge, basic skill, strategies, and ability to coordinate multiple processes. It is known that writing is a 
complex skill to be learned. The writing skill is more complicated than that of other language skills.

Basically, the writing skill requires a wellstructured way of the presentation of thoughts in an organized and planned way (Braine \& Yorozu, 1998) cited in (Javed et al., 2013). Expressing thought in writing is a complex subject, which involves the organization of thought, sound usage of English, and imagination (Langan,1987 p.137). Writing is also very important to fulfil the education requirements, but nowadays students have less interest in writing (Muslim, 2014). Moreover, teachers have to drill students' skill in writing which is based on English standard competence (2006), one of the materials that have to be learned by students of the Junior high school, especially the second grade is about recount text.

According to Knapp (2005), recount text is basically written out to make a report about an experience of a series from the related event. Recount text is a text about something ever happens or about student's experiences in the past. Its purpose is to inform the readers. Recount text has a generic structure and social function that should be understood and applied by students in the way of writing a recount text. In fact, it is so hard for students to master writing skills, especially in writing recount text. Most Students are confused to write their ideas. They can not automatically start to write also they mostly find difficulties on how to continue their writing. Students know or have ideas about what they are going to write but they do not know how to put them into words (Diharyono, 1991). From that problems, it is important for the teachers to select an appropriate technique to build student's writing skills, especially in teaching recount text. One of the techniques that can be chosen in teaching recount text is "guiding question technique".

A guiding question technique is a basic question that direct the students for understanding (Traver, 1998). The guiding question also can be interpreted as questions that mentally influence and lead students' ideas to find the whole thing that is being questioned by the teacher (Wilhelm, 2007). Guiding questions are used to give a chance for students in structuring their sentences (Raimes, 1983). In other words, the guiding question can help students to develop their idea in writing by answering the question that given by the teacher.

There are a lot of studies which has the same topic related to this research. The first is Pertiwi (2013) found that the guided questions technique is helping students in JHS of 3 Tuban to compose text since they just needed to answer the question. The guiding questions technique also helped students to generate their ideas in the writing process. In different line with Pertiwi, Kurniati (2015) looking for another technique that suitable for teaching recount text. Then she tried using the picture to drilled students' skill in writing recount text. Then, the result is using picture technique is effective to teach recount text.

Based on the explanation above, the researcher wants to know the effectiveness of 
guiding question technique to improve students' skills in writing recount text of second grade students at SMP BAKTI NUSANTARA 666, Cileunyi-Bandung. Different case with the previous researches, here the researcher implementing guiding questions in writing recount text for junior high school.

\section{METHODOLOGY}

This research uses a quantitative approach with experimental method. It is aimed to determine whether a variable $(\mathrm{X})$ can improve student's writing skill or not. According to Creswell (2012), quantitative is the best design to research cause and effect relationship. The cause and effect relationship is applied as guiding questions technique gives an effect on the student's writing skill. The dependent variable (Creswell, 2012 p. 295) so does guiding questions technique influence a student's writing skill. The writer uses a quantitative method with an experimental design. Creswell (2012) state, if the design without random assignment, the single-subject design is pre-experimental design. For this reason, this research is pre-experimental which takes one class and consist of pre-test and post-test.

\subsection{Research Participants}

Random group sampling is used as the technique in taking a sample. Then by randomly selected, the researcher take Class for a sample of an experimental group means that non-random class. Then, the researcher takes only one class to make the research more effective and to find out the significant difference between of students' ability in writing recount text before and after using guiding question technique.

Table 1 Sample of Research

\begin{tabular}{c|c|c|c}
\hline Class & Male & Female & Total \\
\hline $8 \mathrm{~A}$ & 18 & 13 & 32 Students \\
\hline
\end{tabular}

\subsection{Reseach Site}

The research is carried out at SMP BAKTI NUSANTARA 666 - Bandung-West Java, Indonesia. The students are chosen from eighth grade. There are two reasons why the researcher chooses this site. The first is because the researcher has an experience of teaching English in this site on teaching practice programme. The second one is because the problem that the researcher found during teaching practice is the lack of students'interest in writing. The school is located in Jl. Percobaan Cileunyi-Bandung.

\subsection{Data Collection Technique (Pre-test and} Post-test)

A pre-test is a set of a test given to students before the treatment begins to determine their ability or knowledge of the content. According to Creswell (2012, p. 297), "a pretest provides a measure on some attributes or characteristics that you assess for participants in an experiment before they receive a treatment". In this stage, students will be instructed to compose a recount text based on the topic chosen. The pre-test is intended to know 
students' writing skill before they are given treatments of research.

A post-test is a measure of some attributes or characteristics those are accessed by participants in an experiment after treatments (Creswell, 2012). After the completion of the treatment, students are through a post-test to know the improvement of after given the treatments. In post-test, students are given a task to write a recount text based on the topic chosen. This test is also used to know the effectiveness of using GDT to improve students writing skill in recount text.

In the post test, there are some guiding questions provided for students to see the difference results of students' writing before using list of guiding questions and after using guidig questions in the pre test and post test. Then, the use of guiding questions also can help students to increase their creativity and their coherence in writing, the GQT in post test is expected stimulate students to produce a good text.

In measuring whether the test had a good validity, the researcher analyzed the test use rubric scoring by Jacob to assess the result of pre-test and post-test. According to Jacob et al. (1981) adapted in Ganiarti (2014), there are five aspects to be scored: content, organization, vocabulary, language use and mechanic. The criteria of the scoring system were based on the rating sheet by Jacob et al. (1981) which concerned with the five aspects of writing.

\subsection{Data Analyzing Technique}

In analyzing the data, this research uses the comparative technique. The score will be compared before and after the treatment is given. This technique is useful to prove statistically the outcomes differences between teaching writing recount text before and after using GQT.

\section{Normality Test}

In this reseacrh, the researcher uses SPSS version 16.00 for Windows to test the normality. In SPSS, there are two kinds of normality test: Kolmogrov Smirnov Test and Shapiro Wilk Test. The criterion of SPSS:

i. If respondents $>50$, the normality test uses Kolmogrov Smirnov.

ii. If respondents $<50$, the normality test used Shapiro Wilk

In this study, the respondents are 31 students, the normality test that can be used was Shapiro Wilk Test. If the significant value of the Shapiro-Wilk Test is higher than 0.05 , the data is normally distibuted. Then, if it is below 0.05 , the data significantly deviate from a normal distribution. The statistical calculation of normality distribution test used Shapiro Wilk test guided by following steps.

The criterion of hypothesis are:

1.) Setting the level significance (p) at 0.05 and establishing the hypothesis

$\alpha=0.05$

- Ho: Significant Score $>0.05$ means the data is normally distributed.

- Ha: Significant Score $<0.05$ means the data is not normally distributed. 
2.) Analyzing the normality distribution with Shapiro Wilk test in SPSS v.16 for windows

3.) Comparing the Asymp.Sig Higher than level of significance $(0,05)$. The null hypothesis or not rejected, while the alternative hypothesis is rejected. It means that the score are normally distributed.

\section{Hypothesis Test}

Hypothesis are predictions the researcher makes about the expected relationships among variables (Creswell, 2012). The testing hypothesis is essential to seek out whether the researcher' claim or the research hypothesis $(\mathrm{Ha})$ is received or not. This research used a paired ttest, it used to test if the means of two paired measurements; pre-test and post-test scores are significantly different. This research uses SPSS V.16 for testing a paired t-test. The criteria of the testing hypothesis are as follow;

$\alpha=0,05$

- If tcount > ttable $\mathrm{Ha}$ is accepted and $\mathrm{HO}$ is rejected; it means there is the significant improvement of students' skills in writing recount text after using guiding questions technique.

- If tcount < ttable $\mathrm{Ha}$ is rejected and $\mathrm{HO}$ is accepted, it means that there is no significant improvement of students' skills in writing recount text after using guiding questions technique.

- If $\operatorname{Sig}(2$ Tailed $)<\alpha$ Ha is accepted and HO is rejected; it means there is the significant improvement of students' skills in writing recount text after using guiding questions technique.

- If $\operatorname{Sig}(2$ Tailed $)>\alpha \mathrm{Ha}$ is rejected and $\mathrm{HO}$ is accepted, it means that there is no significant Guiding Questions Technique To Improve Students' Writing Skills: Recount Text (Siti Nuraeni Muhtar, Lina Rustina, R. Nadia R.P. Dalimunthe) improvement of students' skills in writing recount text after using guiding questions technique.

\section{N-Gain Calculating}

To know the improvement of students' skills in writing recount text, normal gain (d) will be calculated with the formula:

$\mathrm{d}=$ post-test score - pre-test score

maximum score - pre-test score

Normal gain score acquired is then interpreted into the table 3.7:

Table 3. 7 Determaining Gain

\begin{tabular}{c|c}
\hline Percentage & Degree \\
\hline $0-0,3$ & Low \\
\hline $0,3-0,7$ & Medium \\
\hline $0,7-1$ & High \\
\hline
\end{tabular}

\section{RESULT}

\subsection{Pre-test result}

After the researcher collected the data, then the result of pre-test was processing into SPSS 16.0. This process aims to find the minimum score, mean, and standard deviation of pre-test and post-test score that can be seen in the table

Table 4. 2 The Minimum Score, Maximum Score, Mean, Median, Max

\begin{tabular}{l|l|l|l|l|r}
\hline & $\mathrm{N}$ & Min & Max & Mean & Std. Deviation \\
\hline pre-test & 31 & 37.00 & 69.00 & 57.5484 & 8.00766 \\
Valid N & & & & & \\
(list wise) & 31 & & & & \\
\hline
\end{tabular}


It shows that the highest score of pre-test among 31 students before they were taught using guiding questions technique is 69 and the lowest is 37 while the mean is 57 . Based on criteria scale of school regarding English Subject, the result of pre-test is categorized in the "poor to fair' grade. Here is the table of the criteria.

Table 4. 3 Criteria Score

\begin{tabular}{l|l|l|l} 
No & Criteria & \multicolumn{1}{|c}{ Grade } & Score \\
\hline 1. & A & Excellent & $91-100$ \\
\hline 2. & B & Very Good & $81-90$ \\
\hline 3. & C & Good & $71-80$ \\
\hline 4. & D & Fair & $51-70$ \\
\hline 5. & E & Poor & $0-50$ \\
\hline
\end{tabular}

\subsection{Post-test Result}

After the researcher collected the data, then the result of post-test was processing into SPSS 16.0. This process aims to find the minimum score, mean, and standard deviation of pre-test and post-test score that can be seen in the table below.

Table 4. 5 The Minimum Score, Maximum Score, Mean, and Std. Deviation of Post-test

\begin{tabular}{|l|l|l|l|l|r|}
\hline & & Min & Max & Mean & $\begin{array}{c}\text { Std. } \\
\text { Deviation }\end{array}$ \\
\hline post test & 31 & 50.00 & 94.00 & 72.0323 & 8.64671 \\
$\begin{array}{l}\text { Valid N } \\
\text { (list wise) }\end{array}$ & 31 & & & & \\
\hline
\end{tabular}

It shows that the highest score of posttest from 31 students after they were taught using guiding questions technique is 94 and the lowest is 50 while mean is 72 . Based on criteria scale of school regarding English Subject mentioned in the table 4.3 , the result of post-test is categorized in the 'good' grade means that there is a better improvement after taught by using guiding questions technique of the students writing in writing recount text.

\subsection{Analysis Result}

The analysis of pre-test and post-test was done to know the difference score of the students' skills in writing recount text before and after using the guiding questions technique.

The students' condition before taught by this technique was not satisfied, it proven by the result of the mean score is only 57 and referring to the scoring criteria in the table 4.3 it categorized in the 'fair' level. Moreover, after students taught by guiding questions technique then treated by some treatments, it gave a positive effect for students in writing recount text and it can be seen that there is an improvement in students' mean score of pre-test and post-test from 57 to 72 or from the fair level to good level.

In this study, the respondents are 31 students; the normality test that can be used was the Shapiro Wilk Test. If the significant value of the Shapiro-Wilk Test is higher than 0.05 , the data is normally distributed. Then, if it is below 0.05 , the data significantly deviate from a normal distribution. The result of pre-test and post-test score is presented here:

1) The result of the normality test for pretest 
Table 4. 6 Tests of Normality for pre-test

\begin{tabular}{|c|c|c|c|c|c|c|}
\hline & \multicolumn{3}{|c|}{$\begin{array}{c}\text { Kolmogorov- } \\
\text { Smirnov }^{\mathrm{a}}\end{array}$} & \multicolumn{3}{|c|}{ Shapiro-Wilk } \\
\hline & Statistic & $\mathrm{df}$ & Sig. & Statistic & $\mathrm{df}$ & Sig. \\
\hline pre-test & .153 & 31 & .064 & .937 & 31 & .067 \\
\hline
\end{tabular}

a. Lilliefors Significance

Correction

Chart.4 1 Histogram of Pre-test

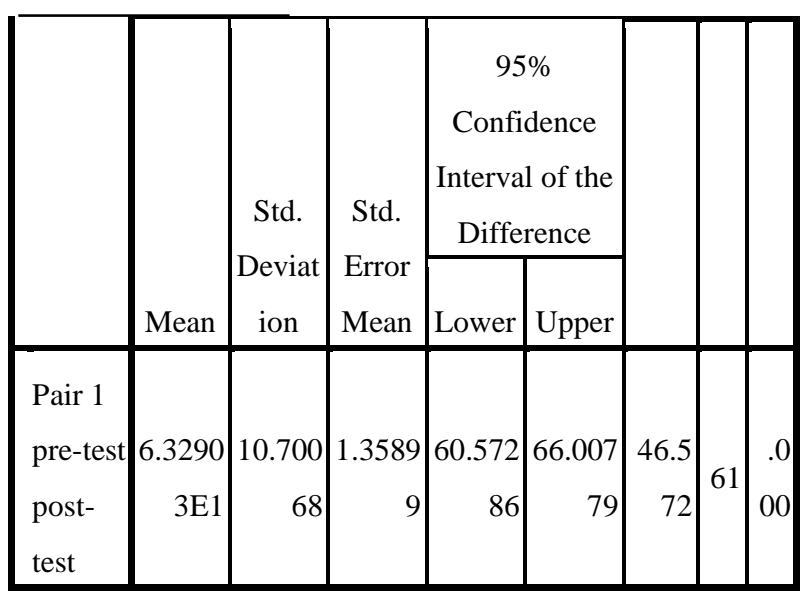

2) The result of the normality test for posttest

Table 4. 7 Tests of Normality for post-test

\section{Chart.4 2 Histogram of normality score for} post-test

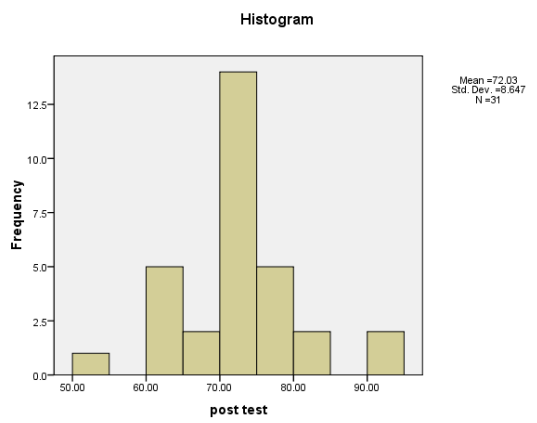

The result of normality test can be seen from both pre-test and the post-test result were getting significances higher than 0,05. Pre-test got 0,067 whereas post-test got 0,224 , so both of them were getting normality distributed.

Guiding Questions Technique To Improve Students' Writing Skills: Recount Text (Siti Nuraeni Muhtar, Lina Rustina, R. Nadia R.P. Dalimunthe) b) Hypotheses

Hypotheses are predictions the researcher makes about the expected relationships among variables (Creswell, 2012). The testing hypothesis is essential to seek out whether the researcher' claim or the research hypothesis $(\mathrm{Ha})$ is received or not. While in SPSS, if the score of Sig.(2tailed) $<0,05$ means that there is significant improvement between pre-test and post-test, then if the score of Sig.(2-tailed) $>0,05$ means that there is no significant improvement between pretest and post-test.

\section{Table 4. 8 Paired Samples Test}
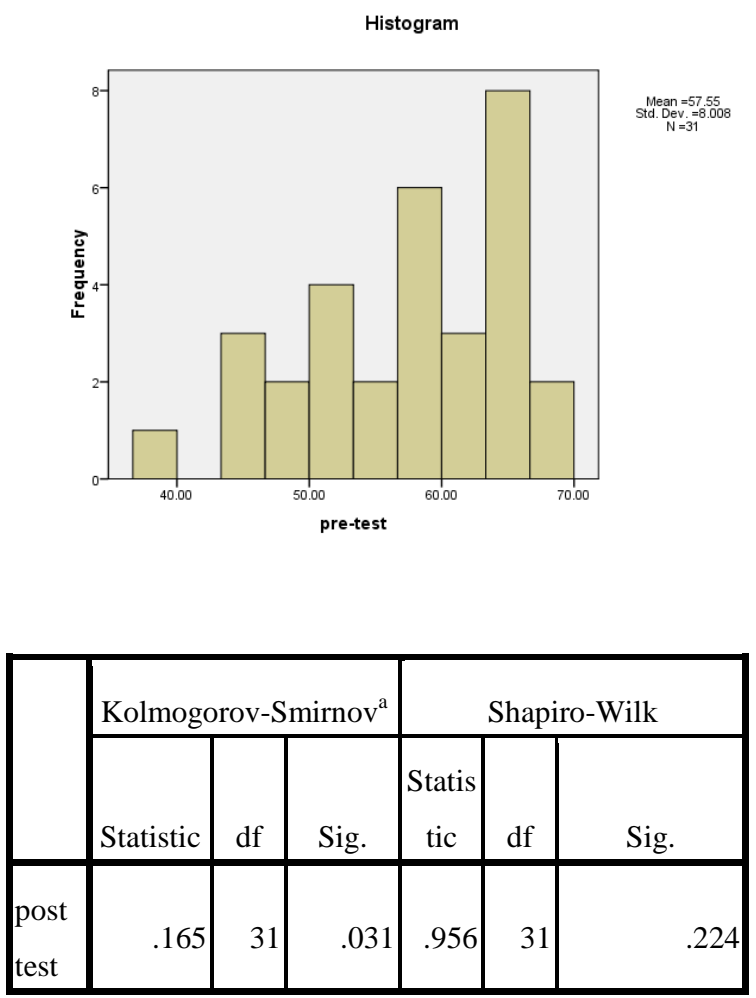

a. Lilliefors Significance

Correction

Based on the statistical data, the result of paired sample test or t-count is 46.572 , while the result of t-table is 1.999 (the list of the table can be shown in the appendix). The determination of result also can be seen from a significant degree 
or $\alpha=0,05 / 2$ and $\mathrm{df} 61$. So, it found that Ho is rejected and $\mathrm{Ha}$ is accepted because $\mathrm{t}$-count = $46.572>$ t-table 1.999. Then, the result of Sig.(2 tailed) is .000 which is less than 0,05 . It means that there is significance improvement of students' skills in writing recount text after using guiding questions technique.

c) N-Gain Result

To find out how significant the difference between students' skills in writing recount text before and after using guiding questions technique, it is required to calculate $\mathrm{N}$ Gain value between pre-test and post-test data (Meltzer, 2002).

Table 4. 9 Determining Gain

\begin{tabular}{c|c}
\hline Percentage & Degree \\
\hline $0-0,3$ & Low \\
\hline $0,3-0,7$ & Medium \\
\hline $0,7-1$ & High \\
\hline
\end{tabular}

The low degree means that the gain is only $0-0,3$. Then, the number of $0,3-0,7$ categorized in the medium degree means that the gain is neither highly or lowly. While the number of 0,7 -1 categorizd in high degree means the gain is very high above medium and low degree. Assessing the gain score is done by using SPSS v.6 for windows, while n-gain score and the average n-gain score are calculated by using Microsoft Excel 2010.

In this research, the researcher found that the result of N-Gain is 0,34 . Based on table 4.10 the score of N-Ggain which is 0,34 is categorized in the medium degree. It means that there is a significant improvement of students' skills in writing after using guiding questions technique and the improvement of students is on the medium degree.

\section{CONCLUSION}

After conducted the research and analyzed the result, the researcher concludes that the previous condition of students before taught by using guiding questions technique is not really satisfied. It can be shown from the mean score of pre-test is 57. On the other hand, the students show their good improvement with the mean score of post-test is 72. Then, after treated by guiding questions technique in the teaching and learning process, the students got the improvement with the improvement level is categorized in medium level. It showed from the $\mathrm{N}$-Gain score 0,34 means that the improvement is not really low also not really high. Moreover, guiding questions technique also gave a good effect for students enthusiasm in writing. 


\section{REFERENCES}

Amalia (2017). The evectiveness of guided questions technique on students' writing skills of recount text.

Anderson, M. \&. (1997). Text type in English. South Yarra: Macmillan Education Australia PTY LTD.

Braine, G. \&. (1998). 'Local area network (LAN) computers in ESL and EFL writing classes'. JALT Journal, 20.

Bramer, G. R. (1981). Writing for readers. Ohio: Charles E.Merill Publishing co.

Brown, D. (1980). Priciples of language learning and teaching. Englewood Cliffs: NJ: Prentice-Hall.

Creswell, J. W (2012). Educational research: planning, conducting, and evaluating quantitative and qualitative research. Boston: Pearson Education.

Derewianka, B (1990). Exploring how texts work. NSW: Primary English Teaching Association.

Derewianka, J. W (2004). Exploring how text work. Newton: PETA.

Diharyono. (1991). 'Teaching writing through story to improve students' writing ability'.

Ganiarti, G (2014). 'The effectiveness of using guiding questions technique to improve students writing ability in writing recount text'.

Geoffrey Broughton, C. B (1980). Teaching English as a foreign language. New York: London and New York.

Harmer, J (2004). How to teach writing. London and New York: Longman Inc.
Headlam, S. M (2014). Research method handbook. CLES.

Huy, N. T (2015). 'Problems affecting learning writing skill of grade 11 at Thong Linh high school'. Asian Journal of Educational Research.

Iwan (2010). 'Developing the students ability in writing recount text through guiding questions technique at the second years students of SMPN 1 Terbanggi Besar Lampung Tengah'.

Jacobs, H. D (1981). Testing ESL composition: a practical approach. Tokyo: Newbury House Publisher, Inc.

Junaidi. (2010). 'Titik presentase distribusi'. Available from http://junaidichaniago.wordpress.com

Knaapp, P. \&. (2005). Genre, text, grammar. In technology for teaching and assessing writing. Sydney: University of New South Wales.

Langan, J (1987). Sentence skills. New York: Mc. Graw Hill Book Company.

Martin, J. R (1985). Process and text. Norwood: Ablex.

Meltzer, D (2002). 'The relationship between mathematics preparation and conceptual learning gains in physics: A possible hidden variable in diagnostic pretest score'.

Muhammad Javed, W. X. (2013). 'A study of students' assessment in writing skills of the English language'. International Journal of Instruction.

Muslim, I. M (2014). 'Helping EFL students improve their writing'. International Journal of Humanities and Social Science. 
Nawai, M. B (2011). 'Improving students' of descriptive text through guided questions'.

Ningrum, M (2015). 'The effect of using guided questioning technique to the students writing ability on recount text at tenth grade students of SMAN 4 Kediri in academic year 2014-20015'.

Ozbek, N (1995). 'Integrating grammar into the teaching of paragraph-level composition'. Forum (online). Vol 33 No. 1. Available From (http//exchanges.state.gov/forum/).

Pendidikan, B. S. (2006). Standar kompetensi dan kompetensi dasar SMP/MTS. Jakarta: Depdikbud.

Pertiwi, N. S (2013). 'The implementation of guiding questions technique to teach writing recount text for the eight graders of junior high school'. Ejournal Unesa.

Raimes, A (1983). Techniques in teaching writing. Newyork: Oxford university press.

Saputri, I (2014). 'Improving students skills in writing recount text by using pictures series for the eight grade students of SMP Muhammadiyah 2 Kalasan in the academic year 2013/2014'.

Saragih, N. S (2014). 'The effectiveness of using recount text to improve writing skill for grade III students of Kalam Kudus elementary school 2 Pematangsiar'. Pemantangsiantar: IQSR Journal of Humanities and Social Science.

Siahaan, S. \& (2008). Generic text structure. Yogyakarta: Graha Ilmu.
Smalley, R. L. (1986). Refining composition skills-rhetoric and grammar for ESL students second edition. New York: Macmillan publishing company.

Tarigan, G. (1987). Menulis sebagai suatu keterampilan berbahasa. Bandung: Angkasa.

Traver, R. (1998). Educational leadership. Alexandria: Assosiation for Supervision and Curriculum Development.

Wilhelm, J. D. (2007). Engaging readers \& writers with inquiry. Scholastic Profesional.

Yulianingsih, N. K. (2017). 'The implementation of guiding questions technique to improve students' recount text writing ability at the first grade students of SMAN 13 Bandar Lampung'. 